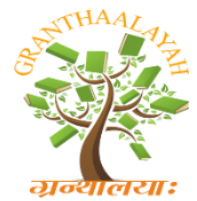

\author{
INTERNATIONAL JOURNAL OF RE
GRANTHAALAYAH \\ A knowledge Repository
}

Social

\title{
CHANDRAKANTBAKSHI'S GUJARATI SHORT STORIES: CONCEPTS, CULTURE AND PROBLEMS OF TRANSLATION INTO ENGLISH AN ANALYSIS
}

\author{
Dr. Joghee Senthil Kumar ${ }^{1}$, Obang Ochalla Ojoho ${ }^{2}$, Gebreegzabhar G ${ }^{3}$, Hiwet G ${ }^{4}$, \\ Yohans ${ }^{5}$, Dagninet Gebey Akalu ${ }^{6}$ \\ ${ }^{1}$ Assistant Professor of English, Gambella University \\ ${ }^{2}$ Faculty of Social Science and Humanities, Gambella University \\ 3, 4, 5 Department of English, Gambella University \\ ${ }^{6}$ Head of the Department of English, Gambella University
}

\begin{abstract}
Translation is a tool of communication in education. Translation is an intelligent activity, requiring creative problem-solving in novel, textual, social and cultural conditions. A translator is the first 'reader' of the other culture as is shown in the foreign language text and he is expected to present the other in a primary process. Cultural substitution is a strategy of replacing the source language (SL) expression with a target language (TL) item that "does not have the same prepositional meaning but is likely to have a similar impact on the target reader". In view of all these, we find it less than convincing to consider the notion of "cultural translation" as a sort of extension or overcoming of the linguistic concept of translation. The concept of culture is fundamental to any approach to translation. The objective of this paper is to discuss the concepts, cultural dimensions and the problems of translation from an Indian language text into English, especially, Chandrakant Bakshi's Gujarati short stories into English language.
\end{abstract}

Keywords: Concept; Culture; Linguistic Concept; Source Language (SL); Target Language (TL); Translation.

Cite This Article: Dr. Joghee Senthil Kumar, Obang Ochalla Ojoho, Gebreegzabhar G, Hiwet G, Yohans, and Dagninet Gebey Akalu. (2019). "CHANDRAKANTBAKSHI'S GUJARATI SHORT STORIES: CONCEPTS, CULTURE AND PROBLEMS OF TRANSLATION INTO ENGLISH AN ANALYSIS." International Journal of Research - Granthaalayah, 7(11), 231-239. https://doi.org/10.29121/granthaalayah.v7.i11.2020.361.

\section{Introduction}

Translation is a tool of communication of two different languages. Especially translation is recognized as an act of culture-specific communication; A translator is the 'first reader' of the other culture as is shown in the foreign language text and he is expected to present the other in a 
primary process. Cultural substitution is a strategy of replacing the source language expression with a target language item that "does not have the same propositional meaning but is likely to have a similar impact on the target reader". (Baker 1992,31). Paraphrasing is the strategy of modifying a source language item in compliance with the target language conventions, so that the translation is readable and intelligible to the target audience. In view of all these, the reader can find it less than convincing to consider the notion of "cultural translation", as a sort of extension or overcoming of the narrowness of linguistic concepts of translation.

The concept of culture is fundamental to any approach to translation. As it is so, we would agree that the "cultural", dimension has always already been included in concepts of translation that emerged from general reflection on language or linguistics. For it is the reflection on language within which the phenomenon of translation was conceptualized in the first place, and it is practices of language through which transitional practices still strongly manifest their implications.

Rupalee Burke, an experienced translator, candidly declares that literary translation is "a creative and spontaneous activity" and what matters actually is a translator's "instincts" and "individual judgments" and not reading or suggestions by others. In this paper, translation of ChandrakantBhakshi's ten Gujarati short-stories into English are explored. The translator's creative use of English in translation of those short- stories is quite critically seen as a discipline and a collective activity for a greater output, and to function as a discipline and a collective activity for a greater output, and to function as a decolonizing agency necessitates theoretical formulation of its strategies and aims. The objective of this paper is to discuss the concepts, cultural dimensions and problems of translation from an Indian language text into English.

\title{
2. ChandrakantBakshi as a Creative Writer
}

The contemporary writer, ChandrakantBakshi (1932-2006) wrote his first short story in Gujarati Makaan Na Bhoot (1951) (The Ghosts of the House) at the age of eighteen. Bakshi wrote novels, short stories, poetry, drama and history. The Gujarati writer was also associated with journalism. His novels and other literary creations have created lasting impression. Bakshi was also associated with many newspapers and magazines. One can see a blend of story writer, a novelist, a historian and journalist in him. His books have been translated into many Indian and foreign languages. Bakshi remained different from his predecessors and his contemporaries in the use of themes, characters, plots and language. He has been bold and unconventional in his themes. This has earned him recognition of being a very radical writer. By establishing himself as a story writer, Bakshi is identified as a distinct modernist, breaking the traditional style of writing.

\author{
In the context of modern literature Bhakshi \\ has been remained an experimenter and \\ modernist writer and yet has been \\ effective and popular. His position is reckoned \\ very high among the most widely read of Gujarati writers.
}

(Encyclopedia of Indian Literature $(1987,332))$ 
Further Sarala Jag Mohan comments on Chandrakantbakshi as a writer thus;

Then there is Chandrakantbakshi, also concerned with

humankind in today's world. His view of life is more earthly, and his style is like a river in spate. His social novels, like Padagha (1978) Doobi Gaya (1958) and Paralysis (1978) and his historical novels, like Ayanvrutta (1967), are gripping with the atmosphere that he builds up with vivid narration of events, effective dialogues, having a sprinkling of Hindi/Urdu words. Bakshi's short stories in Pyar (1958) and other collections are marked by brevity. He creates on limited canvas tiny worlds giving glimpses of real life.

\section{He is eminent as a lively and vibrant creative writer.}

(Jag Mohan 1996,120)

\section{The Concept of Culture}

Through the concept of translation as a communication process, the readers are nourished by felicitating multifarious literatures. Besides that, translation enriches those who study them by offering knowledge of varied culture and societies. Translation is mode of understanding one another. A sequence of negotiation is required to bring two different languages and cultures closer. Thus, the translators acts as a bridge between the two. The literature of different cultures can be introduced by the translators to those who do not know language of that literature.

Robinson remarks, "translation is an intelligent activity involving complex processes of conscious and unconscious learning”. (Robinson: 1997,49). He maintains that creative problem- solving in novel, textual, social and cultural conditions”. (Robinson:1997,51).

In the global culture of the new millennium, the status of English as a link language remains reality. In this present paper, Dharmi Desai introduces ChandrakantBakshi's ten short stories in Gujarati language by translating all of them into English, in which the source language (SL) has certainly helped him in this process of translation. An attempt has been made in this paper to outline the concepts, cultures and problems faced by the translator while translating in general and also specifically in the context of translating ChandrakantBakshi's short stories from Gujarati into English.

On the basis of thematic varieties, ten short stories from different collections of Bakshi's stories have been selected. Among the ten short stories, Anaarhas feminist overtone. Tears are Noiceless presents diaspora of an Indian settled in the U.S. Bakshi'sCold water in an attempt at social criticism. The Deadbody was Nameless is an existential encounter with death, brought out by the literal description of details. Go to Ten House and The Baby Pigeon are tragedies of fate.

January 1, 1998 and Pichola are about man-woman relationship explored in their possible presence and absence. Ma refers to the debatable issue of mercy killing. Good Night Daddy is about the miserable aftermath of divorce. 
In various senses, the translator Dharmi Desai is limited. The observation as the limits of translation carried out by K.Balasubramaiam and D.R.Mohan Raj is as follows:

We must realize; however, the translation is a communication medium, with its own areas of usefulness and its own limitations. The language used in translations, especially of some types of fiction, hardly functions as language per se. We are all familiar with discussions regarding the autonomy available to a translator, the dynamism of a translation, its time-bound relevance (diachronic and synchronic translations of equal value), and so on. Irrespective of the ultimate worth of a translation, it should be recognized that The translator is completely limited in his/her use of the medium that was available For use in its fullest potential to the author of the original. Not only is creative is creative instinct in a translation, the translator's task is further complicated by the host of limitations imposed on him/her by both subject and audience.

\section{Problem of Translation}

(Balasubramniam and Mohan Raj,1988,36)

The problems related to translation from an Indian language into English can be broadly grouped under the categories like the lexical, the cultural and the syntactic/stylistic. In translation, to find cultural equivalence in the context of religious rituals, social customs and mythological references is often problematic. As ChandrakantBakshi wrote his short stories using urbanized Gujarati language only in the urban setting they do not create much problem of this kind. The second category of problem can be found in the linguistic differences between Gujarati and English. These two languages possess different syntactic structure. The structure of Gujarati language is SVD. The sentence structure differs freely from SOV. The sentence structure differs freely from SVD to SOV. A single Gujarati sentence can unite together many simple sentences that on English complex sentence is likely to do so. This would demand a translation strategy of dealing more flexibly with Gujarati syntax.

Tense also creates problems when one tires translate Gujarati tenses into English because time references conveyed by both of them do not correspond with each other. Such issues need to be solved sensitively. It has been an act of maintaining precarious balance between the SL text and the TL text, H.C. Trivedi points out:

While translating from an Indian language into English one is faced with two main problems: First one has to deal with concepts which require an understanding of Indian culture sand secondly, one has to arrive at TL meaning equivalents of references to certain objects in SL culture, which includes features absent TL culture.

(Trivedi:1971,31)

It has rightly been said that translation is not just meant for looking for verbal equivalences but also interpreting a text in one semiotic system with the help of another. 
In lexical and cultural contexts, traditional kinship terms are not translatable. In the story 'Anaar', the mother often addresses her daughter as 'Betaa' or Dikara. 'Betaa' in Gujarati is often used as an affectionate address for a daughter, which 'a son' in English may not convey, e.g.

\author{
1. “BettaBahumodun hare ehhetun.....aajkal” (DV 108) \\ "Betta! You are getting very late.....now adays!" \\ 2. “Pransheetle....Mummy e Kahyun, "badhayrasaavi j ashe, \\ dikaraa!" Logan karsheetlebadhu j enimelegathvayjashe”. (DV 115) \\ "When he gets married........Mummy said, \\ "He will get interested, dikaraa!" \\ When he gets married, everything will \\ be in order in its own way".
}

The same issue also appears in Good Night Daddy! The father started fabricating the story, He addresses his daughter also as 'Betaa' e.g.

\title{
EneKahulun; Betaa, vhelisuijan Aavtikalevheleuthinetaiyar thavunuehhe. (CBSVI) \\ He said ; "Betaa, go to bed" early, Tomorrow: you will have to get up early to get ready.
}

Further in this story and in the story, Go to Ten House, the word 'Maamaa' (maternal uncle), which has no equivalent kinship term in TL culture e.g.

\section{"Khubdurmamaa nun ghar Ehhene, etlebadhedur" (BSV,3) "Very far.As far as the mamaa's home".}

In the same way 'baabaa' is a Gujarati form of address for a male child and 'mamsaheb' is a form of respectful address to a lady, used in Go to Ten House. They are retained as the same in the TL text, e.g.

\section{Hun anebahenfametalevabajar man pahonchyahatan tyan j ek dandy vala e dodtaaavi ne Kahyun: Sa'bbaabaa namathamangheda e laatmarididhichhe. (BSV 102)}

As soon as my sister and I reached the market to buy tomatoes, one dandy's carrier came running and said: Sir, the horse has kicked on baabaa's head.

\section{Char dandyvalaaavyaanebahen ne joine 'memsaheb' dndy!'} Kahetaubharahya, anebahenemathuhalavyu, etlechalyagaya. (CBCV 97) 
Four dandy carriers came and stopped looking at my sister, saying 'memsaheb, dandy !' and she shookher head, so they left.

Another address 'Bhai' literally means 'a brother' but is used as a respectful address to a male, as in the story, 'Anaar' e.g.

Kem?Pelochhokro........" ane mummy e taratsudharilidhun, "Pelabhai..........tanejovaaavyabata, eni mummy sathe.

"Why? That boy" and mummy quickly corrected, "That bhai........

Who came to see you with his mummy".

Further in the TL language 'baby' means a small infant. But here, in the story Good Night Baby, baby is a familiar address in Gujarati language for a girl or a young woman: e.g.

\section{Enejoyuke baby sambhalta}

Sambhaltaj sui gay hati. (CBSV I)

He found that the baby had already fallen asleep while listening to the story not informal and convey is very much close to the friend's mother. He calls her 'maa'. The word 'mother' in English may not convey informal and authentic senses associated with the Gujarati word 'maa' e.g.

\section{Mane 'ma' shabdj game chhe, Sharuaatthi j hue ne 'ma' Kahunchhun.}

I like the word 'maa' only. I have called her 'maa' from the beginning.

In the story Good Night Daddy 'Daddy' is a form of address for a father which is used in educated upper middle class families in Gujarat. So, it is retained as the same in the TL text. The title itself is in English. Traditional kinship terms based on a particular culture or place, are hard and even if they are translated, they lose their appeal and force in the target language (TL). They affect the role of translation. Foot notes are required to solve such problems. Most of Bakshi's short stories are set in the urban milieu, and his characters frequently use English. So whenever English words are used in the SL (Source Language) text, they are presented in italics in the TL (Target Language) text. David Mitchell writes in his award-winning novel, Black Swan Green:

\section{Translating is half poem and half crossword and no doddle, \\ Loads of words aren't actual words you can look up but screws of grammar that hold the sentence together. It takes yonks to find out what they mean; though once you know them you know them. (Mitchell: 2006)}

Lexical items in the SL next referring to local customs, and food items of the SL culture are untranslatable, and they may be retained in the TL text and annotated at the end. The delicacies of Gujarat, Punjab and the South India are retained in English. In the story of 'Pichola', the words in Gujarati like 'lassi'. 'paratha' and 'subji' and in the story, 'Anaar' the name of the South Indian dish,'menduvada'are retained in the TL text. In the story 'Tears are Noiceless', 
The Gujarati food item 'Kichari' is untransferable. It has also the context of folk culture in the story.

While translating a text from the source language (SL) to the target language (TL), the translator has to face many difficult than a creative writer for the latter thinks and writes in one language while the former has to make a tight-rope walking between two languages. The colloquial expressions, culture words, slangs and proverbs are difficult to translate. R.S.Pathak gives a lot of examples in Indian context:

The problems gets complicated because the same form gives different meanings in different languages. The same word gives two different meaning in Marathi and Hindi......Moreover, the translator should be able to differentiate between the denotative, connotative and idiomatic meaning of words. Then, words come to acquire certain associations in language. (Pathak:1994,2)

Language is mostly culture based.Translation is also a form of intercultural communication. It raises problems at verbal and linguistic levels. In the story of 'Cold Water', 'Nawab' means a muslim ruler. But in English it means the governer of a region or a town. There is a word 'raamaa' in the story of 'The Baby Pigeon', that cannot be translated. It means a domestic male servant in Gujarati culture. 'Male servant' in English may not convey the meaning, so it is retained in the TL text. 'Bukhari' and 'Bidi', in the story Go to Ten House cannot be rendered into the TL text.

\section{1. 'Bukharinigaramiman papa e Aasan ne vartaoKahi; eni Angreijikavitoosambhliane e suigoya. (BSV 96)}

The title of the story Cold Water puzzles a translator as the desirability of cold water in Indian hot climate would not be appreciated in English.

\section{Mein panivala ne bolavi ne kartrineni water-bag thandapani Thibharaviaapi. (ESM 41)}

I called the water seller and got kartrine's water bottle filled with cold water.

'Mitraa' is the name of Abhimanyu's wife in the short story Pichola. The literal meaning of this Gujarati common noun is intended in the story, which would suggest that in English. A foot may be a strategy in such a case.

\section{"Abhimanyujaraachhataboltogayo, Enoavajthandopaditogayo. 'dasttakike', Sindhuhasigai, 'etle, tare mane Mitraabanavvichhe? (DV 85)}

Abhimanyu kept saying rather hesitantly, his voice turned sober as a friend- 'Sindhu laughed, so you want me to be Mitraa?' 
Besides,Bakshi has used language creatively. They are many English words which are in currency in informal, day-to-day Gujarati language, which are used innovatively by Bakshi. In the story, Annarof Bakshi, the words, 'stationary' and 'stationery' would differentiate themselves in meaning the moment they are written.

\section{'Stationery? Anaarne hasunaavigayn. 'Stationerry' should Angerjee ma dwiarthihato.Beejoaarthhato: sthgit, athigayelu. Sthir, shithilachal. (DV 114)}

Stationery?Anaarhappened to laugh stationery in terms of pronunciation has a double meaning in English. The other meaning refers to that, which has ceased, stopped. It means steady, stagnant and immovable.

\section{Conclusion}

Talking about translation is a way of translating the unconscious into the conscious, translation has a wide range and levels in human life from translating reality into thoughts, and one's own self and to others. Translation could be a significant educational tool. Translation can also make English studies in India relevant and useful in view of native contexts and requirements.

Translation became an official requirement during the colonial period in India. Thus, translation appears to be a colonizing linguistic transference in certain context. India, emerging fast on the global map in economic and political terms in post-colonial era, needs translation to negotiate with herself and other countries. Further a great deal of Indian literature needs to be translated into English to redress the trend which has been largely the other way round so far.

A translator's sensitivity towards the source language as well as English is required while translating an SL text, rich and complex in itself. While translating Bakshi's short-stories from Gujarati into English, the challenges make the process a memorable experience.

\section{References}

[1] BakshiChandrakantEK Sanj Ni Mulaquat. Ahmedabad: NavbharatSahityamandir 1961.

[2] ChandrakantBakshi Ni ShresthVartao. Ahmedabad: navbharatSahityamandir 1987. (CBSV and page numbers in the paper refer to this context)

[3] Baker, Mona (Ed.) Routledge Encyclopedia of Translations Studies. London and Newyork: Routledge, 1998.

[4] Burke, Rupalee.Tr.2006. The Star Arundhati. Ahmedabad: Flamingo Publications.

[5] Das Vartao.Ahmedabad.NavbharatSahityamandir, 2003. (DV and page numbers in the paper refer to this text).

[6] Balasubramanian, Kamakshi and Mohan Raj D.R., "Contextual Vs Textual specifics: The Limits of Translations" Literature in Translation.Ed. PramedTalgeri and S.B.Verma. Bombay. Popular Prakashan 1988.

[7] Desai RakeshBetween the Self and the Other:Sarup Book Publishers Pvt.Ltd.New Delhi.2013.

[8] Encyclopedia of Indian Literature Vol.1: SahityaAcademi, 1987.

[9] Jag Mohan, Sarala. “Twentieth Century Gujarati Literature."Handbook of Twentieth -Century Literature of India. Eds. NatarajanNalini and Nelson Emanuael Sampth,1996. 
[10] Mitchel David. Black Swan Green. London. Random House, 2007.

[11] Paschim. Ahmedabad: NavabharatSahityaMandir 1976. (PAS and page numbers in the paper refer to this text)

[12] Pathak R.S. “Untranslatabilty: Myth or Reality?” Critical Practice.2: 1, June, 1994.

[13] Patil, Mallikarjun. "Literary Translation" Its importance, Ways and Difficulties".Studies in Translation, Ed. Mohit Ray: New Delhi: Atlantic Publishers and Distributors (P) Lts,2008.

[14] Robinson, D. Becoming a Translator: an accelerated course. London: Routledge, 1997.

[15] Trivedi, H.C. Cultural and Lingistic problems in Translation, Ahmedabad: New Order Book Co., 1971

*Corresponding author.

E-mail address: ghulamhonaryar@gmail.com 